\title{
ON THE SPECTRA OF GENERALIZED FIBONACCI AND FIBONACCI-LIKE OPERATORS
}

\author{
IVAN SLAPNIČAR
}

Abstract. We analyze the spectra of generalized Fibonacci and Fibonacci-like operators in Banach space $l^{1}$. Some of the results have application in population dynamics.

Mathematics subject classification (2010): 47A10, 47N60, 46N60.

Keywords and phrases: Banach space, linear operator, closed operator, unbounded operator, spectrum, Fibonacci sequence, epidemic spread of plant pathogens.

\section{REFERENCES}

[1] S. GoldBerg, Unbounded linear operators, McGraw-Hill, New York, 1966.

[2] C. J. Halberg, Spectral Theory of Linked Operators in $l_{p}, \mathrm{PhD}$ Thesis, University of California, Los Angeles, 1955.

[3] V. V. Prasolov, Polynomials, Springer, Berlin, 2004.

[4] J. A. Powell, I. SlapniČAr AND W. VAN Der Werf, Epidemic spread of a lesion-forming plant pathogen-analysis of a mechanistic model with infinite age structure, Linear Algebra Appl. 398 (2005), 117-140.

[5] A. E. TAYLOR AND D. LAY, Introduction to Functional Analysis, Wiley and Sons, New York, 1980. 